An Introduction to

Electrical Instrumentation

and Measurement Systems 


\section{An Introduction to Electrical Instrumentation and Measurement Systems}

A guide to the use, selection, and limitations of electrical instruments and measurement systems

\section{B.A. Gregory}

Senior Lecturer Specialising in Electrical Instrumentation, Department of Electrical and Electronic Engineering, Brighton Polytechnic

\section{Second Edition}

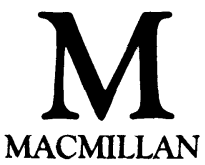


(C) B.A. Gregory 1973, 1981

All rights reserved. No reproduction, copy or transmission of this publication may be made without written permission.

No paragraph of this publication may be reproduced, copied or transmitted save with written permission or in accordance with the provisions of the Copyright Act 1956 (as amended).

Any person who does any unauthorised act in relation to this publication may be liable to criminal prosecution and civil claims for damages.

First edition 1973

Reprinted 1975 (with corrections), 1977

Second edition 1981

Reprinted 1981, 1982 (twice), 1984 (with corrections), 1985

Published by

MACMILLAN EDUCATION LTD

Houndmills, Basingstoke, Hampshire RG21 2XS

and London

Companies and representatives

throughout the world

ISBN 978-0-333-29384-3

ISBN 978-1-349-16482-0 (eBook)

DOI 10.1007/978-1-349-16482-0 


\section{Contents}

Preface $\quad$ ix

1. Introduction 1

1.1 Methods of Measurement 4

$\begin{array}{ll}1.2 \text { Display Methods } & 16\end{array}$

$\begin{array}{lll}1.3 & \text { Accuracy } & 22\end{array}$

$\begin{array}{lll}1.4 & \text { Input Characteristics } & 37\end{array}$

$\begin{array}{ll}1.5 \text { Waveform } & 41\end{array}$

$\begin{array}{lll}1.6 & \text { Interference } & 49\end{array}$

$\begin{array}{lll}1.7 & \text { Selection } & 51\end{array}$

2. Analogue Instruments 53

2.1 Moving Coil Instruments $\quad 53$

2.2 The Electrodynamic Instrument $\quad 97$

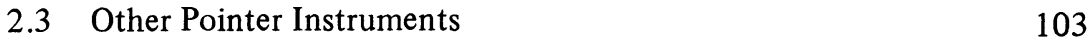

$\begin{array}{lll}2.4 & \text { Energy Meters } & 113\end{array}$

$\begin{array}{lll}2.5 & \text { Solid State Indicators } & 114\end{array}$

$\begin{array}{ll}2.6 & \text { The Cathode Ray Oscilloscope } \\ 2.7 & 115\end{array}$

$\begin{array}{ll}2.7 & \text { Instrumentation Tape Recorders } \\ \end{array}$

3. Comparison Methods 146

$\begin{array}{lll}3.1 & \text { D.C. Potentiometer } & 146\end{array}$

$\begin{array}{ll}3.2 & \text { A.C. Potentiometer } \\ 3.3 & 155\end{array}$

$\begin{array}{ll}3.3 \text { D.C. Bridges } & 156\end{array}$

3.4 A.C. Bridges 166 
4. Digital Instruments 186

$\begin{array}{lll}4.1 & \text { Counters } & 186\end{array}$

4.2 Multi-function Digital Voltmeters 205

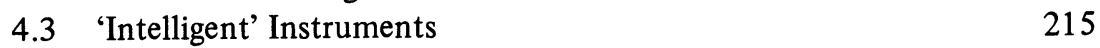

$\begin{array}{lll}4.4 & \text { Hybrid Instruments } & 221\end{array}$

5. Transducers 234

5.1 Resistance Change Transducers 238

$\begin{array}{lll}5.2 & \text { Reactance Change Transducers } & 255\end{array}$

$\begin{array}{lll}5.3 \text { Semiconductor Devices } & 261\end{array}$

$\begin{array}{lll}5.4 & \text { Self-generating Transducers } & 264\end{array}$

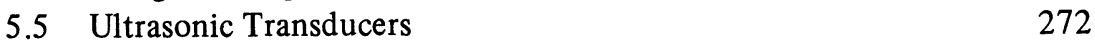

$\begin{array}{ll}5.6 & \text { Digital Transducers } \\ \end{array}$

$\begin{array}{ll}\text { 6. Signal Conditioning } & 277\end{array}$

$\begin{array}{lll}6.1 & \text { Voltage Scaling } & 277\end{array}$

$\begin{array}{ll}6.2 \text { Current Scaling } & 287\end{array}$

6.3 Attenuators 294

$\begin{array}{lll}6.4 & \text { Filters } & 299\end{array}$

6.5 Probes 308

6.6 Modulation and Sampling 316

6.7 Analogue Processing 319

6.8 Digital-Analogue Conversion 329

7. Interference and Screening 331

$\begin{array}{lll}7.1 & \text { Environmental Effects } & 331\end{array}$

7.2 Component Impurities 334

$\begin{array}{lll}7.3 & \text { Coupled Interference } & 341\end{array}$

7.4 Noise Rejection Specifications 349

8. Instrument Selection and Specification Analysis 360

$\begin{array}{lll}8.1 & \text { Instrument Selection } & 360\end{array}$

8.2 Specification Analysis 363

9. Instrumentation Systems 379

9.1 System Design $\quad 379$

9.2 Analogue Systems $\quad 380$

9.3 Digital Systems 384 
CONTENTS vii

10. Problems and Exercises 398

$\begin{array}{lll}10.1 & \text { Principles } & 398\end{array}$

10.2 Analogue Instruments $\quad 400$

10.3 Null or Comparison Measurements $\quad 404$

10.4 Digital Instruments 408

$\begin{array}{ll}10.5 \text { Transducers } & 410\end{array}$

10.6 Signal Conditioning $\quad 411$

10.7 Interference $\quad 413$

$\begin{array}{lll}10.8 \text { Selection } & 415\end{array}$

$\begin{array}{ll}10.9 \text { Systems } & 421\end{array}$

10.10 Answers 422

Appendix I: Units, Symbols and Conversion Factors 425

Appendix II: Dynamic Behaviour of Moving Coil Systems 430

Appendix III: Equations to Determine the components of a Resistive ' $T$ ' Attenuator Pad 


\section{Preface}

Our ability to measure a quantity determines our knowledge of that quantity, and since the measuring of electrical quantities--or other parameters in terms of electrical quantities-is involved in an ever expanding circle of occupations of contemporary life, it is essential for the practising engineer to have a thorough knowledge of electrical instrumentation and measurement systems. This is especially so since in addition to his own requirements, he may be called upon to advise others who have no electrical knowledge at all.

This book is primarily intended to assist the student following an electrical or electronic engineering degree course to adopt a practical approach to his measurement problems. It will also be of use to the engineer or technician, who now finds himself involved with measurements in terms of volts, ampères, ohms, watts, etc., and faced with an ever increasing variety of instruments from a simple pointer instrument to a complex computer-controlled system. Thus, the object of this book is to help the engineer, or instrument user, to select the right form of instrument for an application, and then analyse the performance of the competitive instruments from the various manufacturers in order to obtain the optimum instrument performance for each measurement situation.

During that period of my career when I was employed in the research department of an industrial organisation I was, at times, appalled by the lack of ability exhibited by some graduates in selecting a suitable, let alone the best, instrument to perform quite basic measurements. Since entering the field of higher education to lecture in electrical measurements and instrumentation, my philosophy has been to instruct students to consider each measurement situation on its merits and then select the best instrument for that particular set of circumstances. Such an approach must of course include descriptions of types of instruments, and be presented so that the student understands the functioning and limitations of each instrument in order to be able to make the optimum selection.

There will undoubtedly be comments on and criticisms of this version and for those of the previous edition I am grateful. In this second edition, I have updated the material of the 1973 edition, taking into account the many changes that 
have occurred in instrumentation during the past six years; I have also added instructional problems (a deficiency of the first edition).

I have made appreciable rearrangements to the book, largely to accommodate the changes in instrumentation that have resulted from the developments in integrated circuits, such as the microprocessor, which has made possible programmable and calculating facilities within instruments. Hence, the general theme of the book is to describe the techniques used to produce the various types of instrument available and illustrate their description with examples of manufacturers' specifications. Unfortunately there is a limit to the amount that can be included in a book of realistic size (and price). I have therefore omitted specialised topics such as medical instruments, chemical analysis, radio frequency measurements, acoustic measurements and programming. The last of these topics it might be argued should be included, for more and more instrumentation will involve the use of programmable devices, be it the purpose-built microprocessorcontrolled instrumentation system, or the computer-operated system in which a high level language is used. I would suggest that programming instruction is better documented by the expert rather than by myself. To assist the reader with difficulties of this and other kinds, there is a list of references for further reading at the end of each chapter.

I would like to thank all the instrument manufacturers who have willingly assisted me in producing this volume by providing application notes, specifications, reproductions of articles, and also their obliging field engineers. I have endeavoured to acknowledge all sources of diagrams and other material, but I hope that any oversights will be excused. I should also like to thank my colleagues in the Department of Electrical and Electronic Engineering at Brighton Polytechnic for their assistance and encouragement; in particular my thanks are due to Doctors R. Miller, R. Thomas and K. Woodcock, for reading and commenting on various parts of the manuscript, also to Brenda Foster for patience and effort in typing the manuscript.

B. A. GREGORY 